\title{
Durability of concrete pavement strengthened with asphalt layer with FRP fibres
}

\author{
P. TUTKA ${ }^{1}$, R. NAGÓRSKI ${ }^{2}$, P. RADZISZEWSKI ${ }^{3}$, M. SARNOWSKI ${ }^{4}$, \\ M. ZLOTOWSKA ${ }^{5}$
}

\begin{abstract}
Summary: Pavements made of cement concrete, used for road constructions, are damaged during use. This applies to both the pavements of rural and forest roads with very low traffic loads, as well as road pavements with high traffic loads. One of the most effective ways of repairing damaged concrete cement pavements is through placing an asphalt overlay on a concrete slab. In order to increase the fatigue life of the asphalt overlay, asphalt mixtures are modified with fibres. One technological solution is to use FRP (Fiber Reinforced Polymer), an innovative material with improved properties.

The aim of this paper is to assess the impact of asphalt overlays modified with a new type of fibres to strengthen the durability of weakened cement concrete pavement structures.

On the basis of the conducted analyses, it was shown that the use of an asphalt layer reinforcement increases fatigue life, for both $15 \mathrm{~cm}$ thick prefabricated slabs and a typical road pavement for average traffic made of 25 $\mathrm{cm}$ doweled and anchored concrete slabs. There was a significant increase in the fatigue life of the concrete pavement structure as a result of modifying the overlaid asphalt mixture with FRP fibres.
\end{abstract}

Keywords: concrete pavement, asphalt overlay, FRP fibres, strengthening of cement concrete pavement, fatigue life, FEM analysis

\footnotetext{
${ }^{1}$ MSc, Eng., Warsaw University of Technology, Faculty of Civil Engineering, L. Kaczynskiego 16, 00-637 Warsaw, Poland, e-mail: p.tutka@il.pw.edu.pl

${ }^{2}$ Prof., PhD., Eng., Warsaw University of Technology, Faculty of Civil Engineering, L. Kaczynskiego 16, 00-637 Warsaw, Poland, e-mail: r.nagorski@il.pw.edu.pl

${ }^{3}$ Prof., PhD., Eng., Warsaw University of Technology, Faculty of Civil Engineering, L. Kaczynskiego 16, 00-637 Warsaw, Poland, e-mail: p.radziszewski@il.pw.edu.pl

${ }^{4}$ DSc., Eng., Warsaw University of Technology, Faculty of Civil Engineering, L. Kaczynskiego 16, 00-637 Warsaw, Poland, e-mail: m.sarnowski@il.pw.edu.pl

${ }^{5}$ MSc., Eng., Warsaw University of Technology, Faculty of Civil Engineering, L. Kaczynskiego 16, 00-637 Warsaw, Poland, e-mail: m.zlotowska@il.pw.edu.pl
} 


\section{INTRODUCTION}

Nowadays, in addition to asphalt technology, cement concrete pavement technology is increasingly used in road construction. This especially applies to high-speed roads with a high traffic load [1]. In recent years, the use of concrete technology in low-volume road construction of local roads with very low traffic loads used to service the agricultural and forestry sectors increased [2]. The most commonly used materials are doweled concrete slabs with a thickness of over $20 \mathrm{~cm}$ for road pavements of the traffic load category KR3-KR7, and prefabricated reinforced concrete slabs with a thickness of $15 \mathrm{~cm}$ for very low traffic loads (traffic load below KR1).

Pavements made of cement concrete are damaged over their lifespans. Examples of damage are surface damage, shrinkage cracking, and cracking of edges and corners [3]. An effective and easy way to repair damaged cement concrete pavements is by placing an asphalt overlay on a concrete slab [4]. Such technology allows a quick restoration of the good operational properties of pavements, reduces the development of destructive processes of the concrete surface, and improves anti-noise properties of the pavement. This can be achieved by applying polypropylene [5], polypropylenearamid, carbon, polyester, or cellulose fibres to the asphalt concrete mixture [6]. In civil engineering, reinforced polymer composites are increasingly used [7, 8, 9, 10, 11]. A new technological solution is the modification of the asphalt mixture with innovative basalt-polymer FRP (Fiber Reinforced Polymer) fibers [3]. These fibres used for asphalt mixtures primarily affect the increase of resistance of the pavement to fatigue caused by traffic and thermal loads.

The aim of this paper is to assess the impact of an asphalt overlay modified with a new type of fibres on strengthening the durability of weakened cement concrete pavement structures. Two types of pavement were analysed; the first one made of $15 \mathrm{~cm}$ thick prefabricated slabs for very low traffic loads, and a second one made of doweled and anchored $25 \mathrm{~cm}$ concrete slabs corresponding to a typical road pavement for average traffic loads.

The calculations were based on the results of tests carried out in the experimental section constructed as a part of the PBS research project (Applied Research Program): "Innovative hybrid composite reinforcement FRP for infrastructural constructions with increased durability" carried out at the Warsaw University of Technology. 


\section{ANALYSED PAVEMENT STRUCTURES}

Two types of pavement structures were considered. The first is a pavement structure for low volume roads, e.g. rural roads (structure $\mathrm{S} 1$ - see Fig. 1). In this case, pavement durability was assessed for two types of asphalt layers (asphalt concrete) with Fiber Reinforced Polymer (FRP) (structure denoted by S1-FRP) and without FRP, denoted by S1-NF. The second pavement structure was a typical concrete pavement structure recommended for Polish roads with a traffic category denoted as KR3 (structure S2 - see Fig. 2) [12]. First, the structure without an asphalt overlay was analysed (S2-NA), then the impact of the additional asphalt layer was estimated, again, in two cases, with Fiber Reinforced Polymer (structure denoted by S2-FRP) and without (S2-NF).

A vehicle wheel load equal to $\mathrm{P}=50 \mathrm{kN}$ was assumed (for the standard axle of a $100 \mathrm{kN}$ load), uniformly distributed with intensity $p$ at the circular surface with a radius equalling $r=\sqrt{P / \pi p}$.

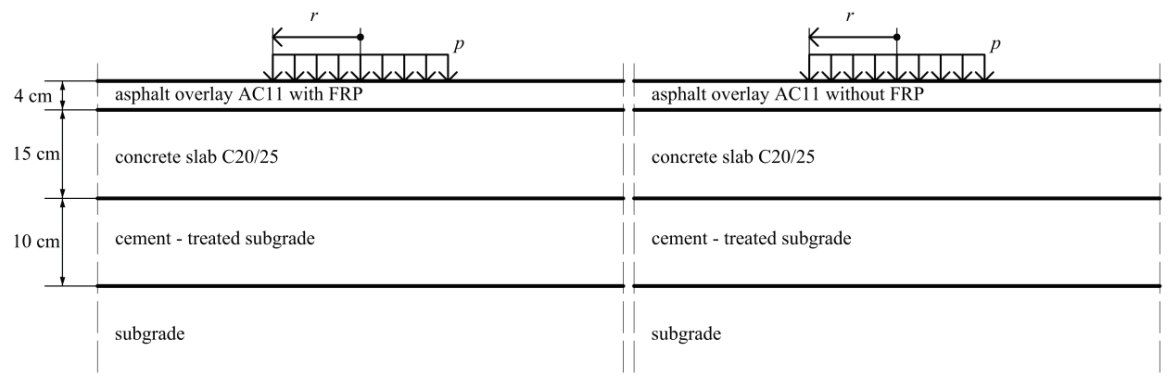

Fig. 1. Pavement structures - case S1 (left: S1-FRP, right: S1-NF)

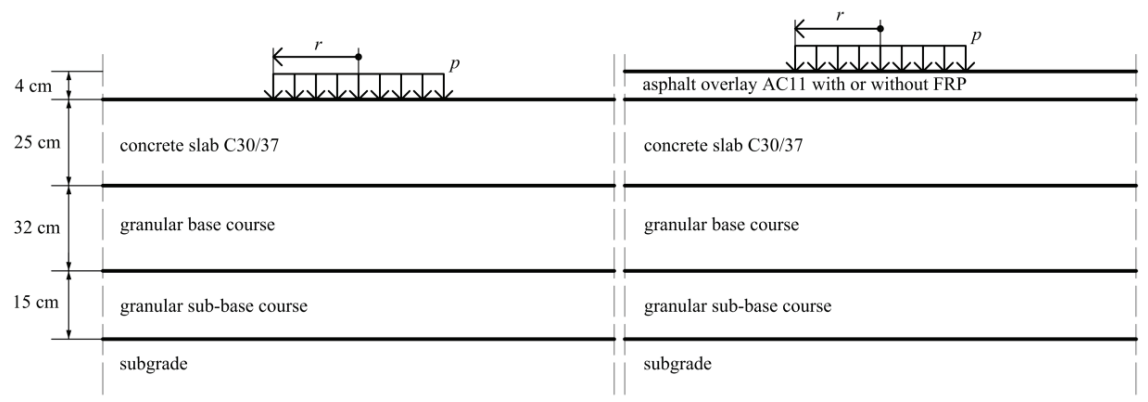

Fig. 2. Pavement structures - case S2 (left: S2-NA, right: S2-FRP and S2-NF) 
Pavement layers were treated as an elastic material obeying Hook's law. The elastic modules was assumed as equal to dynamic stiffness modules for frequency $f=10 \mathrm{~Hz}$ corresponding to typical vehicle speed. The material properties and thickness of layers are presented in Table 1 and Table 2, respectively, for structures S1 and S2. The stiffness modules of the asphalt layers were determined for various temperatures. In the computation, the stiffness moduli for two values of temperatures were used as the elastic moduli of these layers. The temperature was equal to $13^{\circ} \mathrm{C}$ while considering the wheel load and a negative gradient, and the temperature of the asphalt layer was assumed to be $23^{\circ} \mathrm{C}$ for responding to a positive thermal gradient. The stiffness moduli of the concrete varied due to the type of loading [12]. The thermal expansion coefficient of concrete is $1,0 \times 10^{-5}$.

Table 1. Material properties for the low-volume structure

\begin{tabular}{|c|c|c|c|c|}
\hline No & Layer material & $\begin{array}{c}\text { Thickness } \\
{[\mathrm{cm}]}\end{array}$ & $\begin{array}{c}\text { Elastic/stiffness } \\
\text { modulus [MPa }]\end{array}$ & $\begin{array}{c}\text { Poisson's ratio } \\
{[-]}\end{array}$ \\
\hline $1 \mathrm{a}$ & $\begin{array}{c}\text { Asphalt concrete - temperature } 13^{\circ} \mathrm{C} \\
(\mathrm{S} 1-\mathrm{FRP} / \mathrm{S} 1-\mathrm{NF})\end{array}$ & 4 & $12700 / 10700$ & 0,3 \\
\hline $1 \mathrm{~b}$ & $\begin{array}{c}\text { Asphalt concrete }- \text { temperature } 23^{\circ} \mathrm{C} \\
(\mathrm{S} 1-\mathrm{FRP} / \mathrm{S} 1-\mathrm{NF})\end{array}$ & 4 & $10500 / 8800$ & 0,3 \\
\hline $2 \mathrm{a}$ & Concrete slab C20/25 - wheel loading & 15 & 30000 & 0,16 \\
\hline $2 \mathrm{~b}$ & Concrete slab C20/25 - thermal loading & 15 & 26000 & 0,20 \\
\hline 3 & Cement-treated subgrade & 10 & 120 & 0,3 \\
\hline 4 & Subgrade & $\infty$ & 80 & 0,35 \\
\hline
\end{tabular}

Table 2. Material properties for traffic load category KR3

\begin{tabular}{|c|c|c|c|c|}
\hline No & Layer material & $\begin{array}{c}\text { Thickness } \\
{[\mathrm{cm}]}\end{array}$ & $\begin{array}{c}\text { Elastic/stiffness } \\
\text { modulus }[\mathrm{MPa}]\end{array}$ & $\begin{array}{c}\text { Poisson's ratio } \\
{[-]}\end{array}$ \\
\hline $1 \mathrm{a}$ & $\begin{array}{c}\text { Asphalt concrete - temperature } 13^{\circ} \mathrm{C} \\
(\mathrm{S} 2-\mathrm{NA} / \mathrm{S} 2-\mathrm{FRP} / \mathrm{S} 2-\mathrm{NF})\end{array}$ & 4 & $-/ 12700 / 10700$ & 0,3 \\
\hline $1 \mathrm{~b}$ & $\begin{array}{c}\text { Asphalt concrete }- \text { temperature } 23^{\circ} \mathrm{C} \\
(\mathrm{S} 2-\mathrm{NA} / \mathrm{S} 2-\mathrm{FRP} / \mathrm{S} 2-\mathrm{NF})\end{array}$ & 4 & $-/ 10500 / 8800$ & 0,3 \\
\hline $2 \mathrm{a}$ & Concrete slab C30/37 - wheel loading & 25 & 35000 & 0,16 \\
\hline $2 \mathrm{~b}$ & Concrete slab C30/37 - thermal loading & 25 & 26000 & 0,20 \\
\hline 3 & Granular base course & 32 & 400 & 0,3 \\
\hline 4 & Granular sub-base course & 15 & 100 & 0,3 \\
\hline 5 & Subgrade & $\infty$ & 80 & 0,35 \\
\hline
\end{tabular}

For five of the considered structures, key mechanical quantities of the pavement structure were calculated. Fatigue life analysis of the concrete slabs and asphalt layers was conducted for the 
structure with an asphalt overlay. The structure denoted as S2-NA was checked only due to the fatigue life of concrete. For every structure, two types of loading were included: the loading of a vehicle wheel and thermal loading. For both the S1-FRP structure and the S1-NF structure a twophase evaluation was taken into account. First, the fatigue life of the concrete slab was obtained. After some damage of the concrete layers the pavement structure became flexible and the fatigue life of the asphalt layer was assessed. For such cases, the durability in terms of resistance to permanent deformation of the subgrade was calculated as well. In the second phase the assumed elasticity modulus of the concrete slab was equal to $600 \mathrm{MPa}$ [13].

\section{NUMERICAL MODEL}

The Finite Element Method (FEM) was used for obtaining a state of stress and strain. The Abaqus/Standard was used for the calculations. A three-dimensional (3D) computational model was built for every case. Sizes $(h \times a \times b)$ of the concrete slab for structure S1 were equal to $0,15 \mathrm{~m} \times 1,5$ m x $3 \mathrm{~m}$; typical values for precast concrete slabs. For the second structure S2 slab sizes were equal to $0,25 \mathrm{~m} \times 5,0 \mathrm{~m} \times 5,75 \mathrm{~m}$, where the last value represents a sum of the width of two lanes (driving lane and emergency stopping lane).

The following boundary conditions were assumed for the modelled domain: the side surface of the subbase course, the subgrade, and the asphalt overlay were fixed in the perpendicular (horizontal) direction (Fig. 3b). In addition, the bottom base of the domain was fixed in the vertical direction. Another issue was the interaction between the slab and the subbase course. In fact, the interaction between these elements is complex. In the previous version of the Polish requirements for rigid surfaces [14], the degree of cooperation was adopted at a level of $50 \%$, meaning that the slab was partially bonded with the subbase. In this study, two models were assumed: the first one was the full bond of two courses and the second one assumed the possibility of a free slip between the concrete slab and the subbase. The resulting values of stress and strain were the averages of the two analysed models.

The load of the pavement was obtained by the application of a standard vehicle wheel onto the top layer of pavement; a load equalling $50 \mathrm{kN}$. A vertical uniform load of intensity $p=720 \mathrm{kPa}$ was applied to the circular area with a radius of $r=14,87 \mathrm{~cm}$ (Fig. 1). Only for structures S1-FRP and S1$\mathrm{NF}$ was the intensity of the load in the second phase different, equal to $p=850 \mathrm{kPa}$ [1], which gave $r=13,68 \mathrm{~cm}$, because such a pavement structure is semi-rigid. Intensity of the load was assumed according to the Polish design guide [8], [15]. Additionally, thermal loading was included. A linear 
distribution of temperature throughout the concrete slab was assumed. The positive difference of the temperature on the slab surfaces was equal to $10^{\circ} \mathrm{C}$, the negative difference was equal to $4,8^{\circ} \mathrm{C}[16]$. Two locations of the wheel were considered (Fig. 3a):

- vehicle wheel in position P1 - centre of the plate,

- vehicle wheel in position P2 - side of the plate.

For the P1 load and for thermal loading, the model was assumed as in Fig. 4. Symmetry about the $x z$ and $y z$ planes was used and a quadrant model of the road pavement was created. Additionally, a second slab was modelled (Fig. 4 - slab B); this slab interacted with the loaded plate due to the asphalt overlay. For models S2-FBR and S2-NF two additional plates were also included.
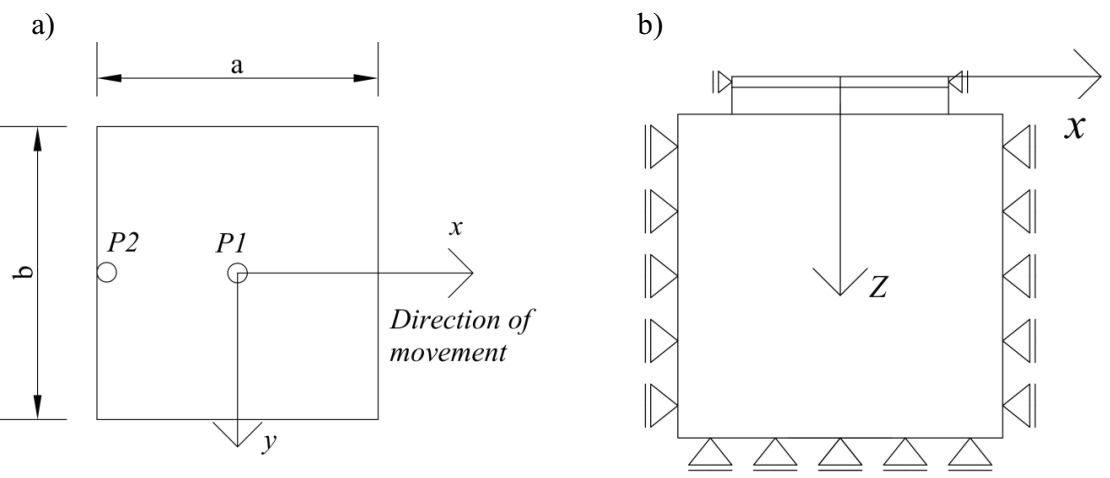

Fig. 3. a) load location b) boundary condition 
a)

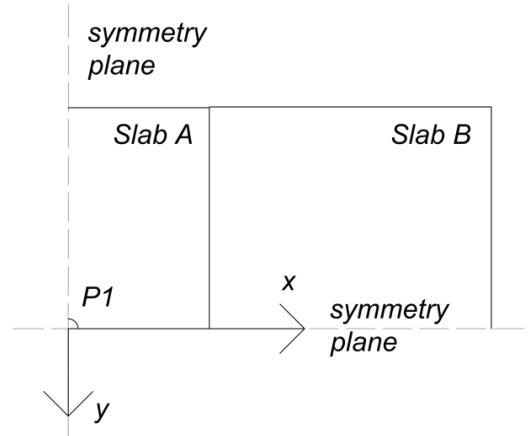

b)

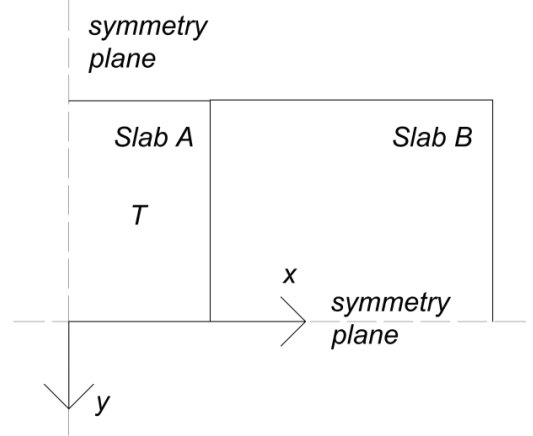

Fig. 4. Scheme model for load P1 (a) and thermal loading (b)

For the P2 load, the model in Fig. 5 was used. Symmetry about the $x z$ plane was used. A half-task model was created. Additionally, a second slab was modelled to include the interaction between slabs (slabs A and B).

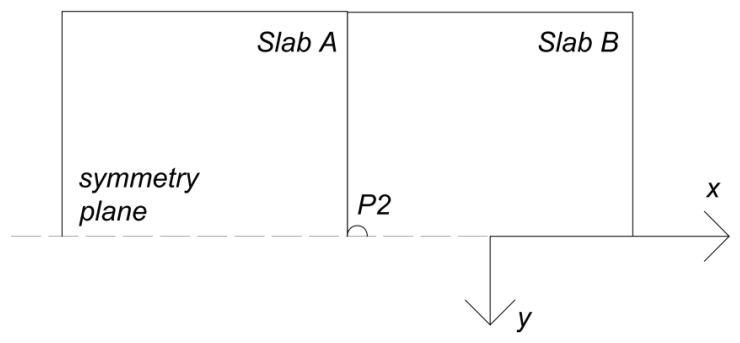

Fig. 5. Scheme model for load P2

For computations of the S1 structure in the second phase the axisymmetric model was used.

\section{FATIGUE MODEL}

The fatigue life of the pavement was calculated with the Miner rule:

$$
\frac{1}{N}=\frac{0,3}{N_{1}}+\frac{0,7}{N_{2}}
$$


where:

$N$ - total fatigue life of the pavement structure, million standard axles $(100 \mathrm{kN}), N_{1}-$ total fatigue life of the pavement structure for the sum of the wheel loading and the thermal loading, million standard axles $(100 \mathrm{kN})$, $N_{2}$ - total fatigue life of the pavement structure for the wheel loading, million standard axles (100 kN).

The expression for fatigue life for the concrete plate is presented as follows [1]:

$$
\begin{gathered}
N_{1}=10^{\frac{1}{0,078}\left(1-\frac{n_{1} \gamma_{m}\left(\gamma_{p} \sigma_{p}+\gamma_{t} \sigma_{t}\right)}{f_{f}}\right)} \\
N_{2}=10^{\frac{1}{0.078}\left(1-\frac{n_{1} \gamma_{m} \gamma_{p} \sigma_{p}}{f_{f}}\right)}
\end{gathered}
$$

where:

$f_{f}$ - flexural strength of the concrete [MPa], $f_{f}=4,5 \mathrm{MPa}, \sigma_{p}$ - maximum value of tensile stress in the concrete slab determined from the wheel load $[\mathrm{MPa}], \sigma_{t}-$ maximum value of tensile stress in the concrete slab determined from the thermal loading [MPa], $n_{1}$ - coefficient of the load transfer between slabs, $n_{1}=0,9-$ structure with dowels (model S2-NA), $n_{1}=0,65$ structure without dowels (used for structures with asphalt overlay due to slab interaction included in computation), $\gamma_{m}$ - material safety factor, $\gamma_{m}=1,3, \gamma_{p}$ - wheel load safety factor, $\gamma_{p}=1,2, \gamma_{t}-$ thermal loading safety factor, $\gamma_{t}=1,2$.

The fatigue life of the asphalt layer was assessed by the maximum tensile strain on the bottom surface and its stiffness according to the following equation of the Asphalt Institute [17]:

$$
N_{f}=18,4 \cdot 10^{M} 6,167 \cdot 10^{-5} \cdot \varepsilon^{-3,291} \cdot E^{-0,854},
$$

where:

$E$ - stiffness/elasticity modulus of the asphalt layer [MPa], $\varepsilon$ - maximum tensile strain on the bottom surface of the asphalt layer $\left[10^{-6}\right]$,

$$
M=4,84\left(\frac{V_{a}}{V_{a}+V_{v}}-0,69\right),
$$

where:

$V_{a}$ - bitumen content $[\% \mathrm{v} / \mathrm{v}], V_{a}=15,5 \%, V_{V}-$ void content $[\% \mathrm{v} / \mathrm{v}], V_{V}=2,4 \%$. 
Durability in terms of resistance of the subgrade to pavement deformation was calculated as follows:

$$
N_{d}=\left(\frac{k}{\varepsilon_{v}}\right)^{1 / m}
$$

where:

$k=1,05 \cdot 10^{-2}, m=0,223$ and $\varepsilon_{\mathrm{v}}$ - maximum compressive strain on the top of the subgrade

\section{RESULTS FOR LOW-VOLUME ROAD STRUCTURE}

For low-volume road pavements, two cases were considered: concrete slabs with an overlay with (S1-FRP) and without (S1-NF) Fibre Reinforced Polymer. First, the fatigue life of the concrete slabs was obtained for both cases. After slab cracking the pavement was treated as semi-rigid. The sum of the fatigue life for two phases was assumed as the total durability of the structure.

\subsection{RESULTS FOR STRUCTURE WITH FRP OVERLAY}

The S1-FRP structure included overlay with Fibre Reinforced Polymer. Table 3 shows the extreme tensile stress in the concrete slab.

Table 3. Stresses and fatigue life for the concrete slab - structure S1-FRP

\begin{tabular}{|c|c|c|c|c|c|c|}
\hline Load location & $\begin{array}{c}\text { Tensile stress } \\
\text { wheel load } \\
{[\mathrm{MPa}]}\end{array}$ & $\begin{array}{c}\text { Tensile stress } \\
\text { thermal loading } \\
{[\mathrm{MPa}]}\end{array}$ & $\begin{array}{c}\text { Sum of } \\
\text { stresses } \\
{[\mathrm{MPa}]}\end{array}$ & $N_{1}$ & $N_{2}$ & $N$ \\
\hline Centre (P1) & 2,009 & 0,751 & 2,760 & 60 & 61166 & 201 \\
\hline Side (P2) & 2,186 & 0,482 & 2,669 & 140 & 11981 & 457 \\
\hline
\end{tabular}

The calculated fatigue life was rather low, equal to 201 standard axels (100 kN axles). It was caused by the relatively low height of the concrete slab $(15 \mathrm{~cm})$, which cannot be compensated by the asphalt overlay. 
Table 4 shows the values of the key strains and fatigue life of the asphalt overlay. Despite the significant maximum strain values $\left(225,33 \cdot 10^{-6}\right)$, the obtained fatigue life for the asphalt overlay was greater than that for the concrete plate. This is caused by high bitumen content in the asphalt layer.

Table 4. Strains and fatigue life for the asphalt overlay - structure S1-FRP

\begin{tabular}{|c|c|c|c|c|c|c|}
\hline $\begin{array}{c}\text { Type of } \\
\text { thermal } \\
\text { loading }\end{array}$ & $\begin{array}{c}\text { Tensile strain } \\
\text { wheel load } \\
{\left[10^{-6} \mathrm{~m} / \mathrm{m}\right]}\end{array}$ & $\begin{array}{c}\text { Tensile strain } \\
\text { thermal loading } \\
{\left[10^{-6} \mathrm{~m} / \mathrm{m}\right]}\end{array}$ & $\begin{array}{c}\text { Sum of } \\
\text { strains } \\
{\left[10^{-6} \mathrm{~m} / \mathrm{m}\right]}\end{array}$ & $N_{1}$ & $N_{2}$ & $N$ \\
\hline $\begin{array}{c}\text { Negative } \\
\text { gradient }\end{array}$ & 179,85 & 45,48 & 225,33 & $2,5 \mathrm{mln}$ & $5,3 \mathrm{mln}$ & $4,0 \mathrm{mln}$ \\
\hline $\begin{array}{c}\text { Positive } \\
\text { gradient }\end{array}$ & 0 & 60,92 & 60,92 & $221,1 \mathrm{mln}$ & $\infty$ & $737,0 \mathrm{mln}$ \\
\hline
\end{tabular}

Additionally, the durability of the pavement structure in the second phase, after cracking of the concrete slab, was calculated. An axisymmetric numerical model was assumed. The obtained tensile strain in the asphalt layer was $164,5 \cdot 10^{-6} \mathrm{~m} / \mathrm{m}$, and the compressive strain in the subgrade was $1101 \cdot 10^{-}$ ${ }^{6} \mathrm{~m} / \mathrm{m}$. It should be noted that principal stresses were not high and the soil did not yield. Fatigue life, determined by the maximum tensile strain, is $N_{f}=7,1$ million standard axles. Durability, in terms of the subgrade's resistance to permanent deformation, was calculated to be $N_{d}=24,7 \cdot 10^{3}$ standard axles. It is worth noting that decisive resistance to permanent deformation in this case is not extremely important for low-volume rural roads. In many cases exceeding this value could be acceptable.

\subsection{RESULTS FOR STRUCTURE WITHOUT FRP OVERLAY}

Structure S1-NF included an overlay without Fiber Reinforced Polymer. Extreme tensile stresses in the concrete slab were higher than for the structure with fibres.

Table 5. Stresses and fatigue life for the concrete slab - model S1-NF

\begin{tabular}{|c|c|c|c|c|c|c|}
\hline Load location & $\begin{array}{c}\text { Tensile stress } \\
\text { wheel load } \\
{[\mathrm{MPa}]}\end{array}$ & $\begin{array}{c}\text { Tensile stress } \\
\text { thermal loading } \\
{[\mathrm{MPa}]}\end{array}$ & $\begin{array}{c}\text { Sum of } \\
\text { stresses } \\
{[\mathrm{MPa}]}\end{array}$ & $N_{1}$ & $N_{2}$ & $N$ \\
\hline Centre (P1) & 2,074 & 0,746 & 2,820 & 34 & 33459 & 116 \\
\hline Side (P2) & 2,289 & 0,484 & 2,773 & 53 & 4640 & 174 \\
\hline
\end{tabular}

The calculated fatigue life was lower than that of the S1-FRP structure, equalling 116 standard axles (100 kN axles). Higher stress was caused by a lower value of the stiffness modulus for the S1-NF structure. 
Table 6 shows the values of the key strains and fatigue life of the asphalt overlay. The maximum value of the tensile strain is equal to $242,11 \cdot 10^{-6} \mathrm{~m} / \mathrm{m}$. It was a significant value, however leading to an asphalt fatigue life equalling 3,8 million standard axles.

Table 6. Strains and fatigue life for the asphalt overlay - structure S1-NF

\begin{tabular}{|c|c|c|c|c|c|c|}
\hline $\begin{array}{c}\text { Type of } \\
\text { thermal } \\
\text { loading }\end{array}$ & $\begin{array}{c}\text { Tensile strain } \\
\text { wheel load } \\
{\left[10^{-6} \mathrm{~m} / \mathrm{m}\right]}\end{array}$ & $\begin{array}{c}\text { Tensile strain } \\
\text { thermal loading } \\
{\left[10^{-6} \mathrm{~m} / \mathrm{m}\right]}\end{array}$ & $\begin{array}{c}\text { Sum of } \\
\text { strains } \\
{\left[10^{-6} \mathrm{~m} / \mathrm{m}\right]}\end{array}$ & $N_{1}$ & $N_{2}$ & $N$ \\
\hline $\begin{array}{c}\text { Negative } \\
\text { gradient }\end{array}$ & 189,29 & 52,82 & 242,11 & $2,0 \mathrm{mln}$ & $4,5 \mathrm{mln}$ & $3,3 \mathrm{mln}$ \\
\hline $\begin{array}{c}\text { Positive } \\
\text { gradient }\end{array}$ & 0 & 64,17 & 64,17 & $216,7 \mathrm{mln}$ & $\infty$ & $722,3 \mathrm{mln}$ \\
\hline
\end{tabular}

Additionally, the durability of the pavement structure in the second phase was calculated. The obtained tensile strain in the asphalt layer was $162,35 \cdot 10^{-6} \mathrm{~m} / \mathrm{m}$, and the compressive strain in the improved subgrade layer was $1124 \cdot 10^{-6} \mathrm{~m} / \mathrm{m}$. Using maximum tensile strains, fatigue life was calculated: $N_{f}=8,6$ million standard axles. Durability, in terms of subgrade resistance to permanent deformation, was calculated as: $N_{d}=22,5 \cdot 10^{3}$ standard axles.

\section{RESULTS FOR TYPICAL CONCRETE PAVEMENT STRUCTURE}

In this section, the results of calculations for the concrete pavement structure recommended for Polish roads are presented (traffic category KR-3). First, the fatigue life of the pavement without the overlay was calculated (M2-NA). Secondly, the impact of the asphalt overlay was considered in two cases: for the overlay with FBR (M2-FBR) and without FBR (M2-NF). The fatigue life of the concrete slab and the asphalt overlay was taken into consideration.

\subsection{TYPICAL CONCRETE PAVEMENT STRUCTURE WITHOUT ASPHALT OVERLAY}

In this section, the results for a typical structure used for rigid pavement construction are presented. This structure is intended for a road with a traffic category of KR3, meaning that its maximum durability is equal to 6,39 million standard axles (axles load $100 \mathrm{kN}$ ) [11]. The results for the S2-NA structure without the asphalt overlay are shown in Table 7. 


\begin{tabular}{|c|c|c|c|c|c|c|}
\hline Load location & $\begin{array}{c}\text { Tensile stress } \\
\text { wheel load } \\
{[\mathrm{MPa}]}\end{array}$ & $\begin{array}{c}\text { Tensile stress } \\
\text { thermal loading } \\
{[\mathrm{MPa}]}\end{array}$ & $\begin{array}{c}\text { Sum of } \\
\text { stresses } \\
{[\mathrm{MPa}]}\end{array}$ & $N_{1}$ & $N_{2}$ & $N$ \\
\hline Centre (P1) & 1,067 & 0,694 & 1,760 & $54 \mathrm{mln}$ & $5489 \mathrm{mln}$ & $177 \mathrm{mln}$ \\
\hline Side (P2) & 1,680 & 0,565 & 2,245 & $2,2 \mathrm{mln}$ & $92,7 \mathrm{mln}$ & $6,8 \mathrm{mln}$ \\
\hline
\end{tabular}

For model S2-NA, the obtained fatigue life was slightly higher than predicted in [11]; durability reaches 6,8 million standard axles.

\subsection{CONCRETE PAVEMENT STRUCTURE WITH FRP ASPHALT OVERLAY}

This section presents results for a rigid pavement structure with an FRP asphalt overlay. The durability of the asphalt layer and the concrete slab was calculated. The results for structure S2-FRP for the concrete slab are presented in the Table 8 .

Table 8. Stresses and fatigue life for the concrete slab - structure S2-FRP

\begin{tabular}{|c|c|c|c|c|c|c|}
\hline Load location & $\begin{array}{c}\text { Tensile stress } \\
\text { wheel load } \\
\text { [MPa] }\end{array}$ & $\begin{array}{c}\text { Tensile stress } \\
\text { thermal } \\
\text { loading [MPa] }\end{array}$ & $\begin{array}{c}\text { Sum of stresses } \\
\text { [MPa] }\end{array}$ & $N_{1}$ & $N_{2}$ & $N$ \\
\hline Centre (P1) & 0,900 & 0,598 & 1,498 & $6,8 \mathrm{mln}$ & $1665 \mathrm{mln}$ & $22,3 \mathrm{mln}$ \\
\hline Side (P2) & 0,980 & 0,519 & 1,499 & $6,7 \mathrm{mln}$ & $795 \mathrm{mln}$ & $21,8 \mathrm{mln}$ \\
\hline
\end{tabular}

The resulting fatigue life of the concrete slab is approximately 21,8 million $100 \mathrm{kN}$ axles. The maximum tensile stress in the plate did not exceed half the flexural strength of the concrete. The asphalt overlay caused a significant increase of the fatigue life. The obtained values of durability were high enough so that structure S2-FRP is suitable for the KR5 traffic category.

In the analysed cases there were significant tensile strains at the joint of two concrete slabs in the asphalt overlay which appeared when the plate was loaded on its side. The thermal load of the concrete slab was taken into account as it affects the stretching of the asphalt overlay in the connection between plates (negative gradient). In addition, thermal stresses occurring in the asphalt layer with a positive temperature gradient were taken into account. In this case, no variant of the vehicle wheel load increased stress caused by thermal loading. The results of the key strains for the asphalt overlay are presented in Table 9.

Table 9. Strains and fatigue life for the asphalt overlay - structure S2-FRP

\begin{tabular}{|c|c|c|c|c|c|c|}
\hline $\begin{array}{c}\text { Type of } \\
\text { thermal } \\
\text { loading }\end{array}$ & $\begin{array}{c}\text { Tensile strain } \\
\text { wheel load } \\
{\left[10^{-6} \mathrm{~m} / \mathrm{m}\right]}\end{array}$ & $\begin{array}{c}\text { Tensile strain } \\
\text { thermal loading } \\
{\left[10^{-6} \mathrm{~m} / \mathrm{m}\right]}\end{array}$ & $\begin{array}{c}\text { Sum of } \\
\text { strains } \\
{\left[10^{-6} \mathrm{~m} / \mathrm{m}\right]}\end{array}$ & $N_{1}$ & $N_{2}$ & $N$ \\
\hline
\end{tabular}




\begin{tabular}{|c|c|c|c|c|c|c|}
\hline $\begin{array}{c}\text { Negative } \\
\text { gradient }\end{array}$ & 19,40 & 85,41 & 104,81 & $31,5 \mathrm{mln}$ & $8120 \mathrm{mln}$ & $104,1 \mathrm{mln}$ \\
\hline $\begin{array}{c}\text { Positive } \\
\text { gradient }\end{array}$ & 0 & 68,04 & 68,04 & $153,7 \mathrm{mln}$ & $\infty$ & $512,3 \mathrm{mln}$ \\
\hline
\end{tabular}

The assessed fatigue life of the asphalt overlay was 104,1 million axles - higher than the durability of the concrete slab. It should be noted that the high durability values for the asphalt overlay (with relatively high strain values) resulted from the high volume fraction of bitumen asphalt in the mix and the small share of voids.

Attention should be paid to the relatively large strains in the asphalt overlay during thermal loading. This is especially noticeable at the so-called negative temperature gradient. Even at a temperature gradient value of $-4,8^{\circ} \mathrm{C}$, thermal deformations reach $85,41 \cdot 10^{-6} \mathrm{~m} / \mathrm{m}$. With other types of thermal loads (taken into account only partially in this study) - a uniform temperature drop over the entire plate height, for example - the value of tensile strains could become crucial for determining the durability of the pavement. Issues such as temperature distribution in the plate under the asphalt layer need further research as only their proper implementation will determine the reliable fatigue life of the asphalt layer due to cracking between concrete slabs.

\subsection{CONCRETE PAVEMENT STRUCTURE WITH ASPHALT OVERLAY WITHOUT FRP}

The results for the S2-NF structure are presented in Table 10; this structure included the overlay without Fiber Reinforced Polymer. The extreme tensile stress in the concrete slab was higher than that in the S2-FRP structure.

Table 10. Stresses and fatigue life for the concrete slab - structure S2-NF

\begin{tabular}{|c|c|c|c|c|c|c|}
\hline Load location & $\begin{array}{c}\text { Tensile stress } \\
\text { wheel load } \\
{[\mathrm{MPa}]}\end{array}$ & $\begin{array}{c}\text { Tensile stress } \\
\text { thermal } \\
\text { loading [MPa] }\end{array}$ & $\begin{array}{c}\text { Sum of stresses } \\
{[\mathrm{MPa}]}\end{array}$ & $N_{1}$ & $N_{2}$ & $N$ \\
\hline Centre (P1) & 0,912 & 0,582 & 1,494 & $7 \mathrm{mln}$ & $1491 \mathrm{mln}$ & $23,1 \mathrm{mln}$ \\
\hline Side (P2) & 1,001 & 0,511 & 1,512 & $5,9 \mathrm{mln}$ & $656,3 \mathrm{mln}$ & $19,4 \mathrm{mln}$ \\
\hline
\end{tabular}

The resulting fatigue life of the concrete slab was approximately 19,4 million axles $100 \mathrm{kN}$. The maximum tensile stress in the slab did not exceed half the flexural strength of the concrete, a value 2,5 million axles lower than that of the S2-FRP structure. 
Table 11 shows the values of the key strains and fatigue life of the asphalt overlay. The maximum value of the tensile strain was equal to $122,77 \cdot 10^{-6} \mathrm{~m} / \mathrm{m}$. It's a significant value, leading however to an asphalt fatigue life equalling 21,7 million standard axles.

Table 11. Strains and fatigue life for the asphalt overlay - structure S2-NF

\begin{tabular}{|c|c|c|c|c|c|c|}
\hline $\begin{array}{c}\text { Type of } \\
\text { thermal } \\
\text { loading }\end{array}$ & $\begin{array}{c}\text { Tensile strain } \\
\text { wheel load } \\
{\left[10^{-6} \mathrm{~m} / \mathrm{m}\right]}\end{array}$ & $\begin{array}{c}\text { Tensile strain } \\
\text { thermal loading } \\
{\left[10^{-6} \mathrm{~m} / \mathrm{m}\right]}\end{array}$ & $\begin{array}{c}\text { Sum of } \\
\text { strains } \\
{\left[10^{-6} \mathrm{~m} / \mathrm{m}\right]}\end{array}$ & $N_{1}$ & $N_{2}$ & $N$ \\
\hline $\begin{array}{c}\text { Negative } \\
\text { gradient }\end{array}$ & 16,52 & 106,25 & 122,77 & $21,7 \mathrm{mln}$ & $12200 \mathrm{mln}$ & $72,0 \mathrm{mln}$ \\
\hline $\begin{array}{c}\text { Positive } \\
\text { gradient }\end{array}$ & 0 & 66,78 & 66,78 & $160,1 \mathrm{mln}$ & $\infty$ & $533,7 \mathrm{mln}$ \\
\hline
\end{tabular}

The resulting fatigue life of the asphalt overlay is 72 million axles, a value greater than the durability of the concrete slab. Finally, the pavement fatigue life value was equal to 19,4 million standard axles $100 \mathrm{kN}$. It is lower than the durability of the surface (durability of the panel) with basalt-polymer fibres in the asphalt overlay.

\section{DISCUSSION OF PAVEMENT STRUCTURE DURABILITY}

In this section, durability values for all considered structures are presented (Fig. 6). It is obvious that the durability of low-volume structures is significantly lower than the fatigue lives of structures intended for medium traffic. However, the fatigue life of the S1 structure is sufficient for application in rural road construction. It's worth noting that the fatigue life of the structure with FRP (S1-FRP) was over $10 \%$ higher than that of the structure without fibres (S1-NF). For a typical concrete pavement structure (denoted as S2-NA), fatigue life was equal to 6,8 million axles. The impact of the application of the asphalt overlay was significant; the fatigue life of the structure with fibres reached 21,8 million axles, and without - 19,4 million axles. Such structures are appropriate for the KR5 traffic category. Application of the asphalt overlay caused a slightly higher durability increase than an additional centimetre of a concrete slab. Fatigue life of the S2-FRP structure was about $12 \%$ higher than that of the S2-NF structure. 


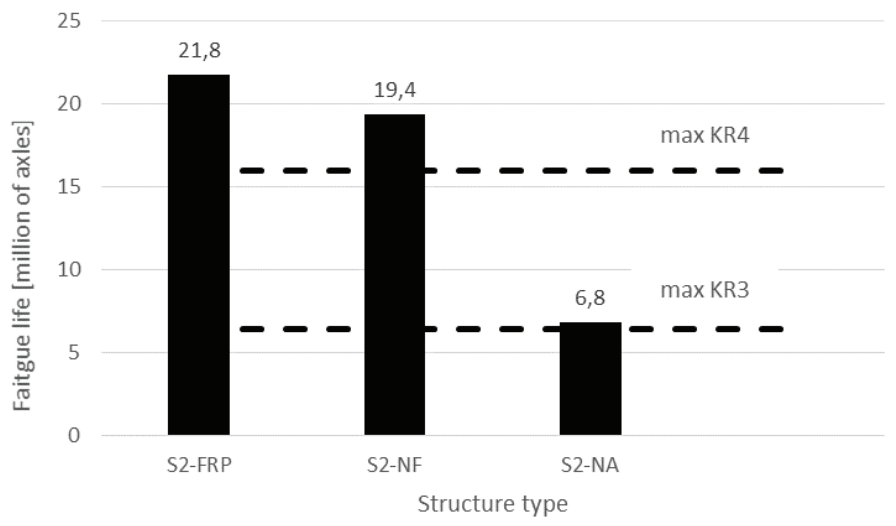

Fig. 6. Fatigue life of pavement structures

It should be noted that there is stretching within the asphalt overlay due to the thermal load on the connection section between two slabs. In the analysed case, tensile strains in the asphalt overlay are not critical for the durability of the structure. However, with a $4 \mathrm{~cm}$ layer of asphalt overlay, extreme thermal strains caused by lowering the temperature of the concrete may cause cracks in the asphalt layer between the slabs. Another important issue which wasn't taken into consideration is concrete shrinkage, which can increase strains in asphalt overlays. 


\section{CONCLUSION}

One of the most effective ways of repairing damaged concrete cement pavements is by placing an asphalt overlay onto a concrete slab. In order to increase the durability of the pavement structure with an overlay, it has proven beneficial to modify asphalt mixtures with the FRP (Fibre Reinforced Polymer). Based on the conducted analyses, it was observed that the use of an asphalt overlay on a concrete slab increases the fatigue life of pavement structures subject to very low local traffic and, to a greater extent, for pavement structures intended for medium traffic.

The low durability of low-volume road structures (according to the adopted empirical criteria) is caused by insufficient plate thickness which is not compensated by the relatively flexible asphalt overlay - even though the FRP overlay is slightly stiffer than the layer without these fibres. When the second phase is considered, pavement fatigue life increases over $10 \%$ due to the addition of FRP. It should be emphasised that durability is the result of resistance to permanent deformation, and the fatigue life of the asphalt layer is significantly higher. In this case, agricultural and forest road pavements may further successfully bear traffic loads.

For the concrete pavement structure for traffic load category KR3, the asphalt overlay with FRP, the pavement fatigue life increased threefold. The noted fatigue life exceeds the requirements for KR4 pavements. Two factors influence the increase in durability: the impact of the asphalt overlay on the rigidity of the pavement, and the interaction between the slabs by the continuous overlay.

In summary, the use of basalt-polymer fibres to modify asphalt overlays for concrete pavements is a current and very important issue in the context of the implementation of a comprehensive road construction program in Poland. 


\section{REFERENCES}

1. Szydło A., Nawierzchnie drogowe z betonu cementowego, Polski Cement, Kraków 2004

2. Budzyński T., Wrzosek M., Wasilewicz-Pszczółkowska M., Szczepańska A., Krupowicz W., GwiaździńskaGoraj M., Goraj S.: Changes in rural areas in Poland. Spatial and technical aspects, GIS-Forum, 2015, Croatian Information Technology Society, GIS Forum, ISBN 978-953-6129-48-5, 88 pages

3. Radziszewski P., Sarnowski M.: Beton asfaltowy zbrojony włóknami FRP do naprawy nawierzchni betonowych, Magazyn Autostrady, ELAMED E. i R. Cholewa Spółka Jawna, nr 10, 2017, ss. 38-41

4. Špaček P., Hegr Z., Varaus M., Hýzl P., Kaděrka R., "Economically effective revitalization of portland cement concrete pavements by asphalt layers overlay”, 6th Eurasphalt \& Eurobitume Congress, 1-3 June 2016, Prague, Czech Republic. DOI: dx.doi.org/10.14311/EE.2016.107

5. Tapkin S., "The effect of polypropylene fibers on asphalt performance", Building and environment, numer 432008, pp. 1065-1071

6. Abtahi S. M., Sheikhzadeh M., Hejaz S. M. "Fiber-reinforced asphalt-concrete - A review", Construction and Building Materials. 24 (2010) pp. 871-877

7. Chandran A., Neelamegam M.: Flexural behaviour of strengthened RC beams with multi-directional basalt fibre - reinforced polymer composites. Archives of Civil Engineering. Volume LXI Issue 1, 2015 DOI: https://doi.org/10.1515/ace-2015-0003

8. Falkowicz K.: Experimental and Numerical Analysis of Compression Thin-Walled Composite Plates Weakened by Cut-Outs. Archives of Civil Engineering. Volume 63 Issue 4. Published: 01 Mar 2018 Page Count: 161172 DOI: https://doi.org/10.1515/ace-2017-0047

9. Gaweł I., Piłat J., Radziszewski P., Kowalski K., Król J.: Rubber modified bitumen. Polymer modified bitumen, properties and characterisation. Edited by Tony McNally. Woodhead Publishing Limited, 2011

10. Krishnaraja A.R., Kandasamy S. Flexural performance of engineered cementitious compositelayered reinforced concrete beams. Archives of Civil Engineering. Volume LXIII Issue 4, 2017 DOI: https://doi.org/10.1515/ace2017-00478

11. Chomicz-Kowalska, A., Iwański, M. M., \& Mrugała, J. Basic Performance of Fibre Reinforced Asphalt Concrete with Reclaimed Asphalt Pavement Produced In Low Temperatures with Foamed Bitumen. IOP Conference Series: Materials Science and Engineering Vol. 245, 2017 DOI:10.1088/1757-899X/245/3/032092

12. Katalog Typowych Konstrukcji Nawierzchni Sztywnych z dnia 16.06.2014 r.

13. Judycki, J., et al. "Katalog typowych konstrukcji nawierzchni podatnych i półsztywnych" Politechnika Gdańska, Katedra Inżynierii Drogowej, GDDKiA, Warszawa (2012): 117.

14. Szydło, A., et al. Katalog Typowych Konstrukcji Nawierzchni Sztywnych z 2001 roku

15. Szydło, A, et al. Katalog Typowych Konstrukcji Nawierzchni Podatnych I Półsztywnych 2012

16. Szydło, A, et al. Aktualizacja katalogu typowych konstrukcji nawierzchni sztywnych. Etap III Raport serii SPR $14 / 2013$

17. AASHTO Guide for the Design of Pavement Structures. American Association of State Highway and Transportation Officials, 1993 